\title{
Introduction
}

\section{\#TogetherApart: Mediatization, (Inter)subjectivity and Sociality at a Time of Pandemic}

\author{
BISSIE ANDERSON, University of Stirling \\ SANTHOSH KUMAR PUTTA, Osmania University
}

It is a popular conception that the COVID-19 pandemic presents a caesura in the course of human history: an unprecedented rupture which brought what we considered 'normal life' to a halt, transforming the ways we live, work, and play. In our collective and individual struggles to overcome the disorientation the pandemic caused and as we look to survive "the cascading crises of the pandemic conjuncture" (Means \& Slater 2021), we are being forced to pause and deeply reflect on the past, and to rethink what we had taken for granted (Harari 2020; Krastev 2020). Hoping to transition to a future of "collective solidarity" and a better "new normal" (Žižek 2020), we simultaneously recognize we are going through a period of heightened volatility. In this "interregnum of transitional ambiguity, if not chaos" (Ang 2021, 611), as we batter through the complexity of our historical moment, we oscillate between utopian and dystopian visions of the future, while subjectively "enduring COVID-19, nevertheless" (Adelman 2021). This endurance manifests in our continued 'labouring', in spite of the grim reality, to maintain some semblance of agency (however illusory) in a world of overwhelming uncertainty: "to invest all our pandemic labours - the doing, undoing, and not-doing - with meaning as a simple but undeniable record of persistence" (Adelman 2021, 470).

The one thing that we have found meaning in has been human connection, which, in conditions of social distance and what in many parts of the world has felt like a never-ending lockdown, has been possible through advanced digital media technologies. These "ecologies of communication through which human life is sustained" (Couldry 2020, 119) have turned into survival mechanisms for a large proportion of the world's population, as digital media proves indispensable in every aspect of our lives. As communication and sociality at a distance replace face-to-face interaction (Fuchs 2020) in the hope that relationships are sustained, symbolized by the popular phrase-turned-hashtag \#TogetherApart, what role does "deep mediatization" (Hepp 2020) play in the COVID-19 pandemic? Will the new social distancing regime and the deepening mediatization of human life and communication further cement the supremacy of technology companies as critical material conditions for cultural practices and social life? How is mediatization changing (or not) personal and public communication, subjectivity, intimacy, and the ways we relate to others? These are some of the questions that inspired this special issue when the call for proposals went out in April 2020, as the world grappled with the new realities of COVID-19 lockdown.

Befitting the complexity of the pandemic conjuncture, this special issue features artistic and early career researcher contributions from a range of disciplines and cultural settings. As 
guest editors, we are proud of the diverse nature of this special issue of Networking Knowledge, in which you will find a total of 12 contributions - academic articles, autoethnographies in the form of short film, collage, and prose-poetry, creative responses to these practice-based contributions, and an in-depth academic expert interview - by researchers and artists hailing from Australia, Bulgaria, China, Germany, India, Portugal, Spain, the UK and the United States.

Zheng Yang's contribution "War metaphors in Chinese digital media coverage of COVID19" opens this special issue. Through a semantic network analysis of The People's Daily coverage of the pandemic on the social media platform Weibo, Yang examines how the public in China are interpellated using mainly "offensive" militarized metaphors "to mobilize and inspire enthusiasm among Chinese people, and to strengthen the Chinese government's control in dealing with the COVID-19 pandemic" (Yang 2021, 9). The types of metaphors explicated particularly resonate with Chinese idioms from the national folklore (e.g., the concept of Waixie), thereby heightening their discursive and rhetorical force. While he recognizes that war metaphors are not a new phenomenon and are common in times of public health crises around the world, Yang argues that the overreliance on them, as discursive strategies, strengthens the paternalistic image of medicine, overemphasizes the obedience of publics to authorities, and undermines personal narratives of people who have experienced the disease. Yang stresses that, as humans, we must learn to live with epidemics and disease, which requires a more diverse stock of metaphors if we are to "rebuild a more harmonious symbiotic relationship between humankind and disease, health and nature" (ibid., 23). This echoes Ang's call for the need to reach beyond our "human horizon to address not just the global, but the planetary challenge facing us", including nature and all the living species on our planet in our visions of the post-pandemic future (Ang 2021, 612).

In the second article of this issue, Sara García Santamaría explores the relationship between the concepts of authenticity and left-wing populism through the performances of the intimate self of two iconic female politicians - Ada Colau (ACO), Mayor of Barcelona, and Alexandria Ocazio-Cortez (AOC), House representative for New York's $14^{\text {th }}$ congressional district. The article uses a comparative case study design, critically analysing the two politicians' discursive constructions of self on Instagram through a visual rhetorical methodology. García Santamaría (2021) maps out the constructions of authenticity of ACO and $\mathrm{AOC}$ along four of the core dimensions of traditional rhetoric - ethos, pathos, topos, and kairos. The findings suggest that left-wing female politicians such as ACO and AOC perform authenticity through posting intimate details from their home lives and surroundings, and thus, construct an inclusionary self-image that revolves around "the notions of intimate and emotional connections with the publics (an element of people-centrism), and anti-elitism" (García Santamaría 2021, 45). In their lockdown Instagram activities, the two politicians were found to engage in complex code-switching between the personal and the professional, presenting themselves as both ordinary women and hardworking, caring politicians, which has enabled them to perform "a sense of virtual ubiquity that makes them more accessible to citizens and, especially, to those who might need their care" (ibid.). 
In "Mediating close friendship intimacy in times of (social) distance", Jeannine Teichert explores how close friends negotiate their relationships from a distance through mediated communications. Grounding the study in the concept of "deep mediatization", Teichert (2021) examines three case studies of distanced close friendships in Germany, developing three core categories through a Grounded Theory approach to account for the different types of mediated intimacies found in the data: distant intimacy, mediated everyday intimacy, and tacit intimacy, respectively. These types of intimacy mediation are tightly interwoven with the media repertoires employed in the communication between the different groups of close distanced friends. Thus, for instance, in the case of distant intimacy, people can find it hard to form local friendships due to the strong emotional bond with their distant friend, therefore feeling "alone among strangers" (ibid., 57). Mediated communication is a poor substitute for this type of intimacy mediation, with face-to-face contact deemed more meaningful.

Mediated everyday intimacy, on the other hand, is defined by friends sharing quotidian and trivial experiences with each other on instant messenger, thus continually renegotiating their close bond (ibid., 58). A third type of friendship negotiation - tacit intimacy - is achieved through more rare, asynchronous communication, whereby the friends are comfortable with the lack of face-to-face or everyday contact and instead, they trust the other person is always there for them (ibid., 59). Although a precursor to the pandemic reality, Teichert's study is pertinent to the 'new normal' of social distancing as it shows the different ways close friendships could be negotiated to overcome feelings of loneliness and maintain close connections.

Anastasiya Maksymchuk's autoethnographic exploration of the concept of mediated intimacy and presence is a personal account of experiencing the death of a close relative during COVID-19 when, due to the lockdown measures, many could not say a final goodbye to their loved ones in person. Maksymchuk's short film "The Paradox of Presence" (2021) poignantly conveys what it feels like to support a relative in their final hours, to witness death, via videocall, raising the question: What does it mean to be there? Maksymchuk further reflects on her experience in a socially distanced interview with Sasha Brovchenko, conducted via Zoom between Lisbon and Kyiv: "Some kind of rationality was guiding me. Maybe that was thanks to the distance, distance is always safe. It protects you from too strong impressions, too heavy emotions, too scary images; it filters and compresses them" (ibid., 71). In her creative response ${ }^{1}$ Katherina Radeva (2021a) provides an interpretation of "The Paradox of Presence", sharing her own reflections on presence and distance as someone with transnational friend and family connections: 'Having "missed" family deaths and many births and many parties, I have often asked myself: "How can my empathy be present from such a vast physical distance?"' (ibid., 73). Radeva concludes that presence is, ultimately, care: a shared experience that involves "an active and informed choice to participate" and "listen deeply" (ibid., 74).

\footnotetext{
${ }^{1}$ Creative response is a short format which is unique to this Networking Knowledge special issue. By deeply engaging with the creative contributions, creative responses enact a mediated dialogue between artists/academics. Symbolically recreating a circle of care, especially due to the personal and intimate nature of the ethnographies, these contributions imbue \#TogetherApart with interpersonal compassion.
} 
The theme of relationship negotiation is continued in Lauren Dempsey's contribution, which explores how friend-based, romantic, familial and professional relationships were maintained through computer-mediated communication during the first UK lockdown in 2020. Based on 18 semi-structured interviews with individuals in England, Dempsey's study (2021) found that her participants quickly became accustomed to computer-mediated communication, with online interactions almost completely supplanting face-to-face communication. The disruption to their day-to-day lives prompted the re-evaluation of participants' relationships and life priorities as they retreated to their personal home bubbles and appreciated the quality time spent with their families (Dempsey 2021, 79-80). However, the majority of Dempsey's study participants found the move from face-to-face to online communication challenging, some missing the comfort of routine interactions and activities, while others having to grapple with the novelties of 'home schooling' and juggling this with working from home (ibid., 81). A third group experienced social discomfort online (ibid., 88), and yet another group found themselves practising subterfuge as they were subjected to surveillance by worried relatives (ibid., 82-83), especially since, in the early days, there were conflicting public messages about how to keep safe and adhere to the pandemic rules. Dempsey concludes that, while computer-mediated communication was a lifeline for many, it was an inadequate replacement to face-to-face interaction and it felt unnatural to participants, pointing to the need to maintain the balance between mediated and face-to-face interactions in modern-day relationships. This conclusion echoes Fuchs (2020), who highlights the challenges of mediated-only interactions when it comes to intimacy: "You cannot hug someone over the Internet," Fuchs observes (396).

Lisette E. Torres' ethnographic art-based contribution "Digital contemplative community in pandemic times" explores the themes of relationality and collective healing. Echoing Means and Slater's observation on the conjunctural struggle to overcome "collective disorientation", and thus, "to articulate collective capacities and forms of agency" $(2021,520)$, Torres uses the medium of collage (Torres 2021,95) to reflect on her Radical Dharma community gatherings and how they helped her "to (re)imagine community and connection during pandemic times" as a disabled Latina mother and scholar (ibid., 94). She positions her contemplation in the pandemic conjuncture, but also in the Black Lives Matter protests on police brutality happening at the time of writing/creation. Brought together by the "need to collectively mend" (ibid., 94), Torres' community's experience and its relational place in the conjuncture is embodied in the collage as a "virtual fugitive space" that "provides our community members a synchronous electronic experience of fellowship and love" (ibid., 96). Radeva's creative response (2021b) contemplates on the associations that the collage generates, especially in relation to time, which is experienced differently during the pandemic than before. Radeva argues that Torres' collage asks us to pause and "allow space for multiple ways of being, space to feel pain and space to heal", but also to "broaden our parallels of being" (ibid., 98). Ultimately, she argues, the collage "prods us into complexity and finding joy in the layers of history" (ibid., 99).

The theme of time and place carries through in "Ever-lockdown: Waiting through times of 
playbour and pandemic in Animal Crossing", in which Merlin Seller critically explores the Nintendo game Animal Crossing: New Horizons as a popular leisurely pandemic activity against the background of "neoliberalism's alienation, isolation and hyperconnected domestic digital labour" (Seller 2021, 100). Challenging popular axiomatic assumptions that the pandemic presents a historic break, Seller argues that Animal Crossing facilitates a "subtle, affective sense of place" amidst what they term "the ever-lockdown" (ibid.). Exploring the subtle 'affects' of the game and its atmospherics, Seller argues that its 'interpassivity' may be seen as a means to externalise and resist "our fantasy of pre-lockdown life" and thus, mediate our ever-lockdown anxiety (ibid., 110). "Pac[ing] back and forth through the weeds" (ibid.), Seller points out, the player relishes the experience of waiting, walking, and dwelling, and in so doing, resists conditions of digital capitalism such as alienation and playbour. With its "quiet, topian radicalism", the author argues, the Animal Crossing world is "an entanglement with continuities and the problematic gradual creep of our neoliberal ever-lockdown enabling an interpassive response to our anxiety" about the progression of neoliberalism (ibid. 111). "This is not a utopia nor a dystopia but somewhere off the beaten path with the horizon always in our eye-line. In a world that disturbs and disquiets, ACNH is not a retreat, but a means of staying in place," Seller concludes (ibid.).

Donnalyn Xu's creative contribution "Transient Feelings" explores the "disorienting experience of navigating loneliness and intimacy in the digital space" (Xu 2021, 117). In her prose poem, consisting of nine stream-of-consciousness vignettes, she investigates the fragmentation of communication and intersubjectivity online, and the "tension between affective relations and isolation, where mediated bodies are troubled by longing, loneliness, and looking" (ibid.). The transience, and existential absurdity, of individual efforts to negotiate the human need for intimacy and relationality in the digital realm, is expressed by $\mathrm{Xu}$ in the following lines (ibid., 119):

vii.

all softness

is defined

by the presence of touch

our relational bodies tell us how we are supposed to feel and $i$ always feel it until i don't

In her creative response, Morven Gow mirrors the format of Xu's poetic contribution, further contemplating on the themes explored in Xu's vignettes, which, as Gow reflects, "describe the loneliness at the heart of a web of spun threads, seeking others to create a connective tissue of threads to build community in a human response to lockdown isolation" (Gow 2021, 121). Gow's creative response concludes with a message of hope - that despite the loneliness, isolation and dislocation in the digital landscape, there is emotion, connection, and love: 
"Yet the digital realm is soul full, filled with eyes and ears eager to devour afresh images every minute of every day" (ibid., 124).

The final contribution to this special issue is an interview with Professor Andreas Hepp, of the University of Bremen, whose seminal work on mediatization and the mediated construction of reality has inspired this special issue. In conversation, we ask Andreas Hepp about his theory of "deep mediatization" and its relation to the COVID-19 pandemic. In the interview (kumar Putta \& Anderson 2021, 125-130), Hepp reflects on the mediated construction, and the deeply mediatized experience, of the pandemic, the rising importance of media and data literacy in this reality, and why pioneer communities of practice, "through their experimental practices and imaginations, [...] lay the ground for possible change" (ibid., 126) when it comes to shaping our mediatized future. He emphasizes the importance of process sociology and relational thinking for understanding intersubjectivity and autonomy and argues that we need "to look at the institutionalization and materialization of digital media as they currently exist" (ibid., 128) before we could ask questions about how to collectively re-imagine media infrastructures to reflect ethical values on a local and global scale. In conclusion, Hepp comments on the contributions to this special thematic issue, pointing out that they show the experience of the pandemic has been "deeply mediatized" (ibid., 129), and that they further scholarly debate on deep mediatization by making this experience "accessible for analytical reflection" (ibid., 130).

We hope that, in its multi-dimensional and multi-layered exploration of the impact of mediatization on sociality and (inter)subjectivity, this special issue has lent some form and texture to the popular pandemic phrase \#TogetherApart. As we emerge from COVID-19 and enter a period of recovery, we will continue the struggle to reimagine, and re-orient ourselves in, a post-pandemic world. Our distanced, mediated experiences (individual, interpersonal and collective) will shape this future reality. The contributions in this special issue could serve as a snapshot of a critical juncture, documenting, through empirical, ethnographic, and dialogic explorations, the human condition in the pandemic conjuncture, and serving as a bridge between the pre-COVID past and the post-COVID "new normal", whenever that comes.

\section{References}

Adelman, R. (2021) Enduring COVID-19, nevertheless, Cultural Studies, 35(2-3), 462474.

Ang, I (2021) Beyond the crisis: transitioning to a better world? Cultural Studies, 35(23), 598-615.

Couldry, N. (2020) Media: Why It Matters. Cambridge, UK: Polity Press.

Dempsey, L. (2021) '"You're not being serious enough!": Renegotiating relationships during lockdown', Networking Knowledge: Journal of the MeCCSA Postgraduate Network, 14(1), 75-93.

Fuchs, C. (2020) "Everyday life and everyday communication in coronavirus capitalism". TripleC 18(1), 375-399. 
García Santamaría, S. (2021) "Politicians stay home": Left-wing populism and performances of the intimate self on social media during the COVID-19 pandemic', Networking Knowledge: Journal of the MeCCSA Postgraduate Network, 14(1), 28-50.

Gow, M. (2021) '"Transient feelings": Creative response', Networking Knowledge: Journal of the MeCCSA Postgraduate Network, 14(1), 121-124.

Harari, Y. N. (2020) 'Yuval Noah Harari: the world after coronavirus.' Financial Times, March $20^{\text {th }}$. Retrieved from: https://www.ft.com/content/19d90308-6858-11ea-a3c91 fe6fedcca75.

Hepp, A. (2020) Deep mediatization. Abingdon and New York: Routledge.

Krastev, I. (2020) "The seven early lessons of the global coronavirus crisis". King's College London Policy Institute, April $7^{\text {th }}$. Retrieved from: https://www.kcl.ac.uk/news/the-seven-early-lessons-of-the-global-coronavirus-crisis

Maksymchuk, A. (2021) "The paradox of presence: Autoethnographic study of life and death via social media", Networking Knowledge: Journal of the MeCCSA Postgraduate Network, 14(1), 67-72.

Means, A. J. \& Slater, G. B. (2021) Collective disorientation in the pandemic conjuncture, Cultural Studies, 35(2-3), 514-522.

kumar Putta, S. K. and Anderson, B. (2021) "Deep mediatization during COVID-19: An interview with Professor Andreas Hepp, University of Bremen", Networking Knowledge: Journal of the MeCCSA Postgraduate Network, 14(1), 125-130.

Radeva, K. (2021a) "'The paradox of presence": Creative response', Networking Knowledge: Journal of the MeCCSA Postgraduate Network, 14(1), 73-74.

Radeva, K. (2021b) “'Digital contemplative community in pandemic times”, Creative response', Networking Knowledge: Journal of the MeCCSA Postgraduate Network, 14(1), 98-99.

Seller, M. (2021) "Ever-lockdown: Waiting through times of playbour and pandemic in Animal Crossing, Networking Knowledge: Journal of the MeCCSA Postgraduate Network, 14(1), 100-116.

Teichert, J. (2021) "Mediating close friendship intimacy in times of (social) distance", Networking Knowledge: Journal of the MeCCSA Postgraduate Network, 14(1), 51-66.

Torres, L. (2021) "Digital contemplative community in pandemic times", Networking Knowledge: Journal of the MeCCSA Postgraduate Network, 14(1), 94-97.

Xu, D. (2021) "Transient feelings: Autoethnographic vignettes on digital intimacy and interiority", Networking Knowledge: Journal of the MeCCSA Postgraduate Network, 14(1), 117-120.

Yang, Z. (2021) "War metaphors in Chinese digital media coverage of COVID-19", 
Networking Knowledge: Journal of the MeCCSA Postgraduate Network, 14(1), 9-27.

Žižek, S. (2020) Pan(dem)ic!: COVID-19 shakes the world. Cambridge: Polity.

\section{Biography}

Bissie Anderson is a doctoral candidate in Journalism at the University of Stirling, Scotland. She was Editor-in-chief of Networking Knowledge in 2019-2020.

Email: bissie.anderson@stir.ac.uk

Santhosh kumar Putta is a UGC - Junior Research Fellow at the Department of Communication and Journalism, UCASS, Osmania University, India.

Email: santoshkera@gmail.com 